Global Conferences Series:

Social Sciences, Education and Humanities (GCSSSEH), Volume 3, 2019

The $1^{\text {st }}$ International Conference on Education, Social Sciences and Humanities

DOI: https://doi.org/10.326/hum0193

\title{
The Performance of Indonesian Wushu Association North Sumatera (Correlation Organization Culture and Management Knowledge with Personnel Performance of Indonesian Wushu Association North Sumatera)
}

\author{
Syahputra Manik \\ Universitas Negeri Medan \\ (*) $\square$ syah.manik16@gmail.com
}

\begin{abstract}
The objective of this research is to find accurate answer scientifically about exist or not correlation between Organization Culture and Management Knowledge with Personnel Performance of Indonesian Wushu Association North Sumatera either working individually or together. This research has been done at Indonesian Wushu Association North Sumatera as much as 30 people and was done on April 2011. This research used correlation approach technique in taking sample of the research by using total sampling. This research concluded: 1) there is a significant correlation between Organization Culture with Personnel Performance of Indonesian Wushu Association North Sumatera, 2) there is a significant correlation between Management Knowledge with Personnel Performance of Indonesian Wushu Association North Sumatera, 3) there is a significant correlation together between Organization Culture and Management Knowledge with Personnel Performance of Indonesian Wushu Association North Sumatera.
\end{abstract}

Keywords: Correlation, Organization Culture, Management Knowledge, Performance, Wushu

\section{Introduction}

Organization is often understood as a group of people who gather and work together in a structured way to achieve a certain goal or a number of targets that have been set together. Organization is a formal form of a group of people with individual goals such as salary, job satisfaction, who work together in a particular process to achieve organizational goals.

Sports organization is a group of people who collaborate by forming organizations to hold sports in accordance with their organization forms and carry out the activities in accordance with the provisions and legislation. A sports organization is an effort to establish cooperation between several people to advance sports activities which are regulated by the prevail rules.

Copyright $\odot$ (2019, the Authors. Published by Redwhite Press.

Page | 39

This is an open access article under the CC BY-NC license

(http://creativecommons.org/licenses/by-nc/4.0). 
The Indonesian National Sports Committee (KONI) is an Indonesian sport organization that assists the government in establishing national policies in the field of founding and developing sport achievements. KONI aims to create a proud sport achievement, build a national character to lift the dignity of the Indonesian people.

The Executive Board of Indonesian Wushu (PB.WI) is one of the members of KONI which is a place to found and develop wushu in Indonesia. North Sumatra is one of the provinces that has very rapid progress in wushu sport, it can be seen from each participating on National Sports Week (PON). At PON XVII East Kalimantan in 2008, wushu became the mainstay sports branch of North Sumatra in obtaining medals and even North Sumatra wushu became the overall champion by obtaining 9 (nine) gold medals, 4 (four) silver medals, and 3 (three) bronze medals, followed by the province of East Kalimantan in the second rank with 3 (three) gold medals, and DKI Jakarta was in the third rank with obtaining 2 (two) gold medals, this result was increased compared with the acquisition in PON XVI 2004 wushu of North Sumatra obtained 5 (five) gold medals and 4 (four) silver medals.

North Sumatra wushu athletes are also medal contributors to the Indonesian contingent in each championship such as 7th International Hong Kong Wushu Championship in 2009, North Sumatra wushu athletes that represent Indonesia won 10 (ten) gold medals. The North Sumatra wushu athlete also donated gold and bronze medals at the World Championships in Toronto Canada.

North Sumatra Wushu is also an area that contributed to the Indonesian team on Sea Games. On Sea Games 2009, athletes from North Sumatra wushu contributed 1 (one) gold medal and 1 (one) silver medal. On Sea Games Palembang Jakarta 2011, 11 (eleven) athletes and 1 (one) coach from North Sumatra wushu participated in the national training camp (platnas).

From the results of North Sumatra's achievements in the implementation of PON East Kalimantan, KONI of North Sumatra conducted an evaluation to improve and increase the program that had been carried out on North Sumatra's achievement founding on the implementation of National Sports Week (PON). The evaluation produced a long-term program, namely KONI Intensive Development Program (PPI) of North Sumatra which aims to prepare North Sumatra athletes for individual or individual sports to participate in PON XVIII 2012 that will be held in Riau. PPI is expected to increase North Sumatra's performance in PON Riau compared with PON in Kalimantan.

To achieve the program objectives that have been made, all parties have to cooperate each other. The managements of the chief sports organization that enter the program must be more serious and improve its performance, with the hope of achieving predetermined and planned goals, as an administrator who has responsibility for the progress of the organization by using authority and leadership to direct others to people's work in achieving its goals.

A good organization culture will improve organization performance, work productivity and work discipline of all members of the organization, and vice versa, poor organization culture will cause decreased performance, productivity, lack of discipline among organizationl members, ineffectiveness of work, failure of achiving goals of organization.

Knowledge management is one of aspects that also greatly affects organization performance. A manager or manager of an organization that has management knowledge, will be able to play a role in achieving the organization goals effectively and efficiently. Managers of organizations that have management knowledge will become the effective managers and become core players in a team that authorizes and encourages others to control their duties and jobs with pleasure and no sense of compulsion. 
Knowledge about management will utter an ability to solve problems and make the right decisions in carrying out management activities. Organization leaders are never separated from management activities in carrying out their duties, functions, authorities and responsibilities. In order the organization goals that have been made successful, so the leader must have management knowledge.

\section{Method}

This study used a survey method with a correlation approach that connects a variable with other variables to find out a phenomenon by determining the level or degree of relationship between these variables. The technique used to measure the level of the relationship between independent variables is; the relationship of Organizational Culture (X1) and Management Knowledge (X2) with the Performance of the Wushu Management of North Sumatra Indonesia (Y).

The sample used in this study was the administrators of the Executive Board of Wushu in North Sumatra Indonesia. The sampling technique is total sampling. The sample in this study is 30 people. Data collection technique was using questionnaire techniques. Data analysis was quantitatively with descriptive statistics and infrential statistics.

\section{Results And Discussion}

The data of this study consisted of the performance of the wushu province management of North Sumatra Indonesia (Y) as a dependent variable, organization culture (X1) and management knowledge (X2) as independent variable.

The Performance of Wushu Province Management of North Sumatra Indonesia

The results of the variable analysis of the performance of provincial managers North Sumatra WI can be stated by the highest score of 171, the lowest score of 137, the average score of 154.80, the standard deviation of 9.48 , the median of 154.50, mode 15. The number of class intervals is 6 and long interval class is 6. Frequency distribution of the data can be seen in table 1.

Tabel 1: The Frequency Distribution of Performance Scores of Indonesian Wushu Province Administrators in North Sumatra

\begin{tabular}{ccc}
\hline Interval class & Absolut frequency (f) & Relative frequency (\%) \\
\hline $137-142$ & 3 & 10,0 \\
\hline $143-148$ & 5 & 16,7 \\
\hline $149-154$ & 7 & 23,3 \\
\hline $155-160$ & 6 & 20,0 \\
\hline $161-166$ & 5 & 16,7 \\
\hline $167-172$ & 4 & 13,2 \\
\hline Total & 30 & 100 \\
\hline
\end{tabular}

The data in table 1 shows that 7 respondents (23.3\%) of the number of respondents obtained scores on the average group, 15 respondents $(50 \%)$ the number of respondents obtained score above the average, and 8 respondents $(26,7 \%)$ the number of respondents obtained score below average.

Organization culture

The results of data analysis can be found that the highest score is 118 , the lowest score is 89 , the average score is 103.93 , the standard deviation is 7.99 , median 104 , modus 98 . The number of class 
interval is class 6 and the length of the interval class is 5 . Frequency distribution of the data can be seen in table 2.

Tabel 2: Score Frequency Distribution of Provincial Board Organizational Culture of Wushu North Sumatra Indonesia

\begin{tabular}{ccc}
\hline Interval class & Absolut frequency (f) & Relative frequency (\%) \\
\hline $89-93$ & 3 & 10,0 \\
\hline $94-98$ & 5 & 16,7 \\
\hline $99-103$ & 6 & 20,0 \\
\hline $104-108$ & 7 & 23,3 \\
\hline $109-113$ & 5 & 16,7 \\
\hline $114-118$ & 4 & 13,3 \\
\hline Total & 30 & 100 \\
\hline
\end{tabular}

The data in table 5 shows that 7 respondents $(23.3 \%)$ of the number of respondents who obtained scores on the average group, 9 respondents (30.0\%) the number of respondents who obtained score above the average, and 14 respondents $(46.67 \%)$ the number of respondents who obtained scores below average.

Management Knowledge

The result of data analysis can be found that the highest score is 31 , the lowest score is 14 , the average score is 23,67 , standard deviation 4,56, median 24, modus 27. The number of interval class is 6 and the length of interval is 3 . The frequency distribution from the data can be seen in Table 3.

Tabel 3: Score Frequency Distribution Management Knowledge of Wushu Province Management North Sumatera Indonesian

\begin{tabular}{ccc}
\hline Interval class & Absolut Frequency (f) & Relative frequency (\%) \\
\hline $14-16$ & 2 & 6,7 \\
\hline $17-19$ & 4 & 13,3 \\
\hline $20-22$ & 6 & 20,0 \\
\hline $23-25$ & 7 & 23,3 \\
\hline $26-28$ & 6 & 20,0 \\
\hline $29-31$ & 5 & 16,7 \\
\hline Total & 30 & 100 \\
\hline
\end{tabular}

The data presented in Table 6 shows that the 7 respondents $(23.3 \%)$ of respondents earn scores on average group, 11 respondents (36.67\%) of respondents who obtained a score above the average, and 12 respondents $(40.0 \%)$ of respondents who obtained a score below average.

Hypothesis Testing

The Relationship between Organizational Culture with the Wushu Provincial Board Performance North Sumatra Indonesia

The results of testing the data with simple linear regression analysis towards the variable of organizational culture (X1) with the performance of wushu province management of North Sumatra 
Indonesia $(\mathrm{Y})$ produced a regression coefficient $\mathrm{b}$ of 0.885 and a constant of 62.85 . The form of the relationship between the two variables can be expressed by the regression equation $\widehat{Y}=62,85+0,885 X_{1}$.

Test of significance and linear regression equation $\widehat{Y}=62,85+0,885 \mathrm{X}_{1}$ used analysis of F-test variance (ANAVA). The criteria is significant if Fcount is greater than F-table, so the regression equation is declared significant while the linear test criteria, if F-count is smaller than Ftable, then the regression equation is declared as linear. The calculation of the significance test and the linear equation $\widehat{\mathrm{Y}}=62,85+$ $0,885 \mathrm{X}_{1}$ can be seen in Table 4 below:

Tabel 4: Analysis of Variance (ANAVA) for Significance Test and Linearity of Simple Linear Regression

\begin{tabular}{cccccc}
\hline Source of Varians & Dk & JK & RJK & F-count & Ftable(0,05) \\
\hline Total (T) & 30 & 721498 & & & \\
\hline Regression (a) & 1 & 718891,20 & & & \\
\hline Regression (b/a) & 1 & 1447,92 & 1447,92 & $34,98^{* *}$ & \\
\hline Residu & 28 & 1158,88 & 41,39 & & 4,56 \\
\hline Suitable Tunq & 23 & 995,88 & 43,30 & $1,33 n s$ & \\
\hline Galat & 5 & 163,00 & 32,60 & & \\
\hline
\end{tabular}

The results of the analysis of variance above can be concluded that the form of the relationship between organizational culture $(X 1)$ and the performance of wushu province management of North Sumatra Indonesia $(\mathrm{Y})$ is meaningful and linear, thus the regression equation model can be used to predict.

The calculation result of the coefficient correlation (ry1) by using product moment made after testing of significance and the linearity test can be seen in Table 5 .

Tabel 5 : Significance Test of Coefficients Correlation between Organizational Culture and the Performance of Wushu Province Management of North Sumatera Indonesia

\begin{tabular}{cccccc}
\hline Correlation & $\alpha$ & $\mathrm{r}$ & $\mathrm{r} 2$ & tcount & ttable \\
\hline $\mathrm{X} 1$ and $\mathrm{Y}$ & 0,05 & 0,745 & 0,555 & $5,91^{*}$ & 1,70 \\
\hline
\end{tabular}

Significance test of the correlation between organizational culture (X1) with the performance of wushu province management of North Sumatra Indonesia $(\mathrm{Y})$ as seen in table 10 obtained tcount $=5.91$ greater than ttable $=1.70$ at the significance level $\alpha=0.05$, so it can be concluded that the correlation coefficient ry1 $=0.745$ significant.

The relationship between Knowledge Management with the performance of wushu province management of North Sumatra Indonesia

The results of the testing data with a simple linear regression analysis towards the management knowledge variable (X2) with the performance of wushu management of North Sumatra Indonesia (Y) 
produced a regression coefficient $\mathrm{b}$ of 1.319 and a constant of 123.58 . The form of the relationship between the two variables can be expressed by the regression equation $\widehat{Y}=123,58+1,319 \mathrm{X}_{2}$.

Test of significance and linear regression equation $\widehat{Y}=123,58+1,319 \mathrm{X}_{2}$ used analysis of F-test variance (ANAVA) Ftest. The criteria is significant if Fcount is greater than Ftable then the regression equation is stated to be significant while the linear test criteria, if Fcount is smaller than Ftable then the regression equation is declared a liner. Calculation of the significance test and linear equation $\widehat{Y}=$ $123,58+1,319 X_{2}$ can be seen in table 6 below.

Tabel 6 : Analysis of Variance (ANAVA) to Test the Significance and Linearity of Simple Linear Regression

\begin{tabular}{cccccc}
\hline $\begin{array}{c}\text { Source of } \\
\text { Variance }\end{array}$ & dk & JK & RJK & Fcount & Ftable(0,05) \\
\hline Total (T) & 30 & 721498 & & & \\
\hline Regression (a) & 1 & 718891,20 & & & \\
\hline Regression (b/a) & 1 & 1048,71 & 1048,71 & $18,85^{* *}$ & 4,20 \\
\hline Residu & 28 & 1558,09 & 55,65 & & 2,55 \\
\hline Suitable Tunq & 14 & 784,42 & 56,03 & $1,01 \mathrm{~ns}$ & \\
\hline Galat & 14 & 773,67 & 55,26 & & \\
\hline
\end{tabular}

The results of the variance analysis above can be concluded that the form of the relationship between management knowledge $(X 2)$ and the performance of the wushu province management of North Sumatra Indonesian $(Y)$ is meaningful and linear. This regression equation model implies that if the management knowledge is increased by one score, the performance tendency of wushu management of North Sumatra Indonesia increases by 1,319 scores on the constant 123,58. The results of the calculation of correlation coefficient (ry2) by using the product moment are carried out after testing the significance and linearity test can be seen in table 10 .

Tabel 12 : Significance test of correlation coefficients between Knowledge Management with the Performance of province Wushu management of North Sumatra Indonesia

\begin{tabular}{cccccc}
\hline Correlation & $\alpha$ & r & r2 & tcount & ttable \\
\hline$X 2$ and $Y$ & 0,05 & 0,634 & 0,402 & $4,34^{*}$ & 1,70 \\
\hline
\end{tabular}

The significance test of the correlation between management knowledge $(\mathrm{X} 2)$ and the performance of wushu province management of North Sumatra Indonesia $(\mathrm{Y})$ as seen in table 12 obtained tcount $=4.34$ greater than ttable $=1.70$ at the significance level $\alpha=0.05$, so it can be concluded that the correlation coefficient ry $2=0.634$ is significant. $\mathrm{H} 0$ means that there is no relationship between management knowledge and the performance of wushu province management of North Sumatra Indonesia is rejected, and $\mathrm{H} 1$ is accepted. This finding concludes that there is a significant relationship between management knowledge and the performance of wushu province management of North Sumatra Indonesia. This means that the higher the management knowledge, the higher the performance of wushu province management of North Sumatra Indonesia that is achieved.

This result also shows the coefficient of determination of 0.402 ; this means that $40.2 \%$ of the performance of wushu province management of North Sumatra Indonesia is explained by management knowledge variables. 
The Relationship between Organizational Culture and Knowledge Management with the performance of Wushu province of North Sumatra Indonesia

The results of data testing with simple linear regression analysis towards organizational culture variables (X1) and management knowledge (X2) with the performance of wushu province management of North Sumatra Indonesia $(\mathrm{Y})$ produced a regression coefficient b of 0.686 for $\mathrm{X} 1$ and 0.788 for $\mathrm{X} 2$, and constant a 64.846 . The form of the relationship between the three variables can be expressed by the regression equation $\widehat{Y}=64,846+0,686+0,788 \mathrm{X}_{2}$.

Test of significance and linear regression equation $\widehat{Y}=64,846+0,686+0,788 \mathrm{X}_{2}$, uses variance analysis (ANAVA) Ftest. The criteria is significant if Fcount is greater than Ftable, so the regression equation is stated significant while the linear test criteria, if Fcount is smaller than Ftable then the regression equation is declared as linear. The calculation of test for significance and linear equations $\widehat{\mathrm{Y}}=64,846+0,686+0,788 \mathrm{X}_{2}$ can be seen in table 13 below:

Tabel 13 : Summary of the Results of Multiple Regression Analysis between Organizational Culture and Management Knowledge with the Performance of Wushu Province in North Sumatra Indonesia

\begin{tabular}{cccccc}
\hline Source of Varians & $\mathrm{dk}$ & $\mathrm{JK}$ & RJK & Fcount & $\begin{array}{c}\text { Ftable } \\
(0,05)\end{array}$ \\
\hline Reduction total & 30 & 721498 & & & \\
\hline Regression & 2 & 1749,40 & 874,70 & & $27,54^{* *}$ \\
\hline Residu & 27 & 857,40 & 31,76 & & 3,35 \\
\hline
\end{tabular}

The results of the analysis of variance above can be concluded that the form of the relationship between organizational culture (X1) and management knowledge (X2) with the performance of wushu province management of North Sumatra Indonesia $(\mathrm{Y})$ is meaningful and linear. This regression equation model implies that if the organizational culture and management knowledge is increased by one score then the performance tendency of wushu provincial management of North Sumatra Indonesian increases by $0.686+0.788$ scores on constant a is 64.846 .

The calculation of multiple correlation coefficients is continued after testing the significance and linearity of multiple linear regression equations, illustrated in table 14.

Tabel 14 : Results Summary of Multiple Correlation Analysis between Organizational Culture and Management Knowledge with the Performance of Wushu province management of North Sumatra Indonesia

\begin{tabular}{ccccccc}
\hline $\begin{array}{c}\text { Correlati } \\
\text { on }\end{array}$ & $\mathrm{N}$ & $\mathrm{R}$ & $\mathrm{R} 2$ & Fcount & Ftable & $\begin{array}{c}\text { Explanatio } \\
\mathrm{n}\end{array}$ \\
\hline Ry12 & 30 & 0,819 & 0,671 & 27,54 & 3,35 & Significant \\
\hline
\end{tabular}

The calculation results obtained that Ry12 multiple correlation coefficient obtained by the $\mathrm{R}$ value $=$ 0.819. The F test obtained Fcount $=27.54>$ Ftable $=3.35$ at a significant level $\alpha=0.05$. The multiple correlation coefficients that obtained in this study are very significant. These findings reject H0, means there is no meaningful relationship between organizational culture (X1) and management knowledge (X2) with the performance of wushu province management of North Sumatra Indonesia (Y) and H1 is accepted, means there is a positive relationship between organizational culture (X1), and management knowledge (X2) with the performance of wushu province management of North Sumatra Indonesia (Y). 


\section{Conclusion}

Based on the research result and hypothesis testing, it can be concluded that: 1) There is a significant relationship between organizational culture and the performance of wushu province management of North Sumatra Indonesia, 2) There is a significant relationship between management knowledge and the performance of wushu province management of North Sumatra Indonesia, 3) There is a jointly significant relationship between organizational culture and management knowledge with the performance of wushu province management in North Sumatra Indonesia.

\section{References}

Adam, Geoffrey. (2001). Efective Management in Extension Edvisory in Central and Estern European, Counttries. Retrieved from http://www.fao.org.

Atmodiwiro, Subagio. (2000). Managemen Pendidikan Indonesia. Jakarta:PT Arda dizya Jaya.

Bloom, Benyamin S. (1981). Taxonomy of Educational Objectives : Cognitive Domain. New York: Longman.

Cushway, Barry and Derek Lodje. (1995). Organizational Behavior and Design, Translate Sularno Tjiptowardoyo. Jakarta: PT. Elex Media Komputindo.

Davis, Keith and Jhon W. Newstrom. (1996). Perilaku dalam Organsasi. Translate Agus Dharma. PT : Erlangga, Seventh Edition.

Downelly Jr, James L. Gibson and M. Ivancevich. (1987). Fundamental of Management. Illionis : BPI Irwin.

Drucker, Peter F. (1997). An Introductory View of Management. New York : Harper and Row Publisher Inc.

Fathoni, Abdul Rahmat. (2006). Organisasi dan Manajemen Sumber Daya Manusia. Jakarta: PT. Rineka Cipta.

Gray, Edmund R and Larry R. Smeltzer. (1990). Management the Competitive Edge. Singapore: Mac Millan Publishing Company.

Haiman, Scot and Connor. (1982). Management. Boston: Houghton Mifflin Company.

Hani, Handoko T. (2003). Manajemen. Yogyakarta: BPFE-Yogyakarta, 2nd Edition.

Hasibuan, Malayu. (2009). Manajemen. Jakarta: Bumi Aksara.

Kreither, Robert and Angelo Kinicki.(2003). Perilaku Organisasi, Book I, Translate Erly Suandy. Jakarta: PT Salamba Emban Patria.

Lakein, Alan. (1997). How to Get Control of Your Time and Life. Translate by Reika Harahap. Jakarta : PT. Pustaka Tangga.

Lanto, Sandra and Stefanie. (1997). Beat Stress With Strength. USA: Park Avenue Production.

Ruasch, Erwin and Herbert Sherman. (2001).Practical Tools for Effective Management Leadership Development. Retrieved from http://www.Esc.Edu.com

Sherman, Arthur, George Bohlander and Scott Shell. (1996). Managing Human Resources. USA: South Western Collage Publisher.

Sudjana. (1992). Metode Statistik. Bandung : Tarsito. 